\title{
EFEKTIVITAS PELAYANAN PEMBUATAN KARTU TANDA PENDUDUK ELEKTRONIK (E-KTP) PADA KANTOR KECAMATAN BAAMANG KABUPATEN KOTAWARINGIN TIMUR
}

\author{
Riri Gustiana
}

\begin{abstract}
ABSTRAK
Salah satu permasalahan dalam pelayanan publik di tingkat Kecamatan yang sering dikeluhkan masyarakat adalah pelayanan dalam pembuatan Kartu Tanda Penduduk Elektronik (e-KTP). Seperti halnya pada pemerintah Kecamatan Baamang, masih terdapat permasalahan-permasalahan. Di satu sisi usaha pemerintah setempat memberikan pelayanan sudah berjalan cukup baik namun disisi lain masih ditemui permasalahan-permasalahan yang tetap muncul pada proses pelayanan publik, seperti kurangnya komunikasi, permasalahan waktu antrian yang panjang dan lama, serta kurang disiplinnya aparatur dalam melaksanakan tugasnya.

Menyadari pentingnya e-KTP, diharapkan pemerintah mampu menyediakan pelayanan pembuatannya kepada publik dengan baik dan benar. Pelayanan tersebut harus efektif, agar terciptanya kepuasan bagi masyarakat yang memerlukan pelayanan. Penelitian ini bertujuan untuk mengetahui efektivitas pelayanan pembuatan e-KTP serta faktor-faktor yang mempengaruhinya pada kantor Kecamatan Baamang.

Metode penelitian yang digunakan adalah metode penelitian deskriptifkualitatif yakni dengan menggambarkan fenomena yang terjadi sesuai kenyataan dilapangan serta untuk mengetahui dan mempelajari kondisi alamiah yang tidak dimanipulasi oleh peneliti yang mengandung makna sebenarnya. Populasi dalam penelitian ini adalah Pegawai pada Kantor Kecamatan Baamang dan masyarakat yang memiliki e-KTP.

Berdasarkan hasil penelitian dan penganalisisan data, maka diperoleh hasil yaitu efektivitas pelayanan pembuatan e-KTP pada Kantor Kecamatan Baamang dikategorikan belum efektif sesuai tujuan yang diinginkan oleh organisasi, meskipun pegawai yang ada sudah menguasai teknis pekerjaannya, memberikan informasi dengan akuntabel dan transparan serta pegawai memiliki kemampuan yang handal baik dalam hal pendidikan, pengalaman maupun pembinaan kerja yang baik. Tetapi belum dapat ditunjang oleh kurangnya fasilitas alat perekaman data e-KTP yang serta kurang disiplinnya pegawai. Hal tersebut sangat mempengaruhi kepuasan masyarakat yang menerima pelayanan maupun kualitas pelayanan yang diberikan oleh aparatur.
\end{abstract}

Kata Kunci: Efektivitas, Pelayanan Publik, Kualitas

\section{PENDAHULUAN}

Sebagai konsekuensi dari pelaksaan otonomi daerah, terlebih setelah ditetapkannya Undang-Undang Nomor 32 tahun 2004 tentang Pemerintah Daerah, 
maka pemerintah daerah diberi kewenangan yang demikian luas dari pemerintah pusat untuk mengatur rumah tangganya sendiri, termasuk didalamnya adalah pemberian pelayanan yang sesuai dengan Standar Operasional Pelayanan (SOP).

Terkait dengan kewenangan Daerah Otonom, bahwa Pemerintah telah mengeluarkan Undang-Undang Nomor 23 tahun 2006 tentang Administrasi Kependudukan yang berbunyi :

"Menimbang :

a. bahwa untuk memberikan perlindungan, pengakuan, penentuan status pribadi dan status hukum setiap Peristiwa Kependudukan dan Peristiwa Penting yang dialami oleh Penduduk Indonesia dan Warga Negara Indonesia yang berada di luar wilayah Negara Kesatuan Republik Indonesia, perlu dilakukan pengaturan tentang Administrasi Kependudukan;

b. bahwa pengaturan tentang Administrasi Kependudukan hanya dapat terlaksana apabila didukung oleh pelayanan yang profesional dan peningkatan kesadaran penduduk, termasuk Warga Negara Indonesia yang berada di luar negeri;

c. bahwa peraturan perundang-undangan mengenai Administrasi Kependudukan yang ada tidak sesuai lagi dengan tuntutan pelayanan Administrasi Kependudukan yang tertib dan tidak diskriminatif sehingga diperlukan pengaturan secara menyeluruh untuk menjadi pegangan bagi semua penyelenggara negara yang berhubungan dengan kependudukan;

Berkaitan dengan hal diatas, maka seiring dengan pelaksanaan otonomi daerah, Kabupaten Kotawaringin Timur sebagai salah satu daerah otonom selalu dituntut untuk melaksanakan kewenangan daerahnya dengan memberikan kesejahteraan kepada masyarakat, bangsa dan Negara yang dicerminkan lewat kinerja aparatur pemerintah dalam memberikan pelayanan kepada masyarakat yang sesuai dengan perkembangan teknologi dan pertumbuhan serta peningkatan kebutuhan dasar masyarakat. Titik berat otonomi daerah saat ini adalah desa/kecamatan, dimana pelayanan yang paling dekat dengan masyarakat secara langsung. Oleh karena itu pelaksanaan pelayanan publik sangat penting untuk diperhatikan.

Perbaikan kinerja birokrasi pelayanan publik mempunyai implikasi luas terutama dalam tingkat kepercayaan masyarakat kepada pemerintah. Salah satu permasalahan dalam pelayanan publik di tingkat Kecamatan yang sering dikeluhkan masyarakat adalah pelayanan dalam pembuatan Kartu Tanda Penduduk Elektronik (eKTP), program e-KTP merupakan program yang diluncurkan oleh Kementrian Dalam Negeri Republik Indonesia pada bulan Februari 2011. Program e-KTP dilatar belakangi oleh sistem pembuatan KTP konvensional/Nasional di Indonesia yang memungkinkan seseorang dapat memiliki lebih dari 1 KTP dan digunakan untuk hal-hal yang dapat merugikan negara seperti, kegiatan kriminal, menghindari pajak, dsb. Dalam hal ini pemerintah kabupaten/kota harus segera meninjau pelaksanaan pelayanan e-KTP agar dapat terlaksana dengan baik dan efektif. Sehingga dalam setiap pelayanan kebutuhan masyarakat, pemerintah harus menjadikan e-KTP sebagai syarat dalam pelayanan urusan dan kebutuhan masyarakat yang dilayani. Pelayanan kepada masyarakat yang 
diberikan oleh aparatur pemerintah seringkali cenderung rumit seperti dalam hal : a). tata cara pelayanan, b). rendahnya pendidikan aparatur, dan c). disiplin kerja.

Program e-KTP merupakan Kartu Tanda Penduduk yang dibuat secara Elektronik dalam artian baik dari segi fisik maupun cara penggunaanya berfungsi secara komputerisasi, sehingga diperlukan perhatian khusus dalam pelayanannya terlebih pada kondisi masyarakat yang masih awam dengan program e-KTP. Hal ini sangat penting untuk diperhatikan karena mengingat e-KTP merupakan identitas yang wajib dimiliki setiap warga negara seperti yang tercantum dalam UU No. 23 Tahun 2006 tentang Administrasi Kependudukan pada BAB V Pendaftaran Kependudukan pasal 13 (ayat) 1 yang menyatakan bahwa : "setiap penduduk wajib memiliki NIK". NIK yang dimaksud disini adalah Nomor Induk Kependudukan yang ada di e-KTP, NIK inilah yang nantinya akan dijadikan dasar dalam membuat berbagai jenis dokumen Identitas (SIM, Paspor, NPWP,dsb.).

Adapun kewenangan dari pemerintah Kecamatan Baamang dalam hal pelayanan pembuatan e-KTP yakni Camat dalam perspektif ini memiliki posisi penting dan fungsi yang sangat strategis, sekaligus kejelian dalam memahami kondisi daerahnya, bagi perkembangan munculnya kebijakan-kebijakan pemerintahan yang lebih tinggi, yaitu pemerintah kabupaten/kota, dan peran penting camat lainnya adalah kemampuannya dalam memenuhi kebutuhan masyarakat daerahnya, yakni pelayanan melalui kebijakan-kebijakan internal organisasi kecamatan misalkan dengan memberikan pelayanan yang transparan dan akuntabel.

Berdasarkan latar belakang diatas, maka pokok masalah yang diteliti adalah sebagai berikut: (1) Bagaimana Efektivitas Pelayanan Pembuatan e-KTP pada Kantor Kecamatan Baamang, Kabupaten Kotawaringin Timur?; (2) Apa saja faktor yang mempengaruhi Efektivitas Pelayanan Pembuatan e-KTP pada Kantor Kecamatan Baamang, Kabupaten Kotawaringin Timur?

\section{KERANGKA TEORITIS}

\section{Efektivitas}

Handoko (1997) dalam Zuliyanty (2005:26), Efektivitas merupakan kemampuan untuk memilih tujuan yang tepat atau peralatan yang tepat untuk pencapaian tujuan yang telah ditetapkan. Sedangkan Richard M. Steers mengemukakan tentang tiga buah konsep yang saling berhubungan, yaitu: (1) Optimalisasi Tujuan yaitu bagaimana kita melihat pada pencapaian target kerja, apakah sudah sesuai dengan yang telah direncanakan atau tidak. Kita juga melihat apakah ada keluhan yang datang dari masyarakat tentang pelayanan yang diberikan pegawai sudah baik atau tidak, sebab dengan adanya keluhan berarti menunjukan tujuan organisasi belum tercapai seppenuhnya; (2) Perspektif Sistematika yaitu melihat pada kemampuan masingmasing pegawai dalam menyelesaikan pekerjaan sesuai dengan kedudukannya dalam organisasi tersebut, apakah pegawai mampu mengerjakan tugasnya dalam kemampuan sendiri, apakah pegawai memiliki keterampilan atau keahlian khusus; dan (3) Perilaku pegawai dalam organisasi yaitu bagaimana tingkat ketelitian pegawai dalam 
melaksanakan pekerjaannya, baik ketelitian dalam hal keberhasilan maupun tingkat kesalahan yang mungkin terjadi pada saat bekerja. Bagaimana kita melihat pada kecepatan dan ketepatan waktu pegawai dalam menyelesaikan pekerjaannya, bagaimana konsentrasi pegawai dalam bekerja.

\section{Pelayanan Publik}

A.S. Moenir (2002:26-27) mendefinisikan pelayanan sebagai kegiatan yang dilakukan oleh seseorang atau sekelompok orang dengan landasan tertentu dimana tingkat pemuasannya hanya dapat dirasakan oleh orang yang melayani atau dilayani, tergantung kepada kemampuan penyedia jasa dalam memenuhi harapan pengguna. Pelayanan pada hakikatnya adalah serangkaian kegiatan, karena itu proses pelayanan berlangsung secara rutin dan berkesinambungan, meliputi seluruh kehidupan organisasi dalam masyarakat. Proses yang dimaksudkan dilakukan sehubungan dengan saling memenuhi kebutuhan antara penerima dan pemberi pelayanan.

Suatu pelayanan akan dapat terlaksana dengan baik dan memuaskan apabila didukung oleh beberapa faktor:

1. Kesadaran para pejabat pemimpin dan pelaksana

2. Adanya aturan yang memadai

3. Organisasi dengan mekanisme sistem yang dinamis

4. Pendapatan pegawai yang cukup untuk memenuhi kebutuhan hidup yang minimum

5. Kemampuan dan keterampilan yang sesuai dengan tugas/pekerjaan yang dipertanggung jawabkan

6. Tersedianya sarana pelayanan sesuai dengan jenis dan bentuk tugas/pekerjaan pelayanan. (Moenir, $2000: 123-124$ ).

Menurut Parasuraman dalam Lupiyoadi (2001), untuk dapat menilai bagaimana mutu pelayanan publik yang diberikan oleh aparat birokrasi, sekiranya perlu adanya kriteria dimensi yang menunjukan suatu pelayan publik yang diberikan itu dapat dikatakan baik atau buruk. Ukuran kualitas pelayanan tidak hanya ditentukan oleh penyedia layanan saja akan tetapi justru lebih banyak ditentukan oleh para pengguna layanan, dalam hal ini adalah masyarakat. Terdapat lima demensi kualitas pelayanan, yaitu :

1. Tangible, atau bukti fisik yaitu kemampuan dalam menunjukkan eksitensinya kepada pihak eksternal. Yang dimaksudkan bahwa penampilan dan kemampuan sarana dan prasarana fisik dan keadaan lingkungan sekitarnya merupakan bukti nyata dan pelayanan yang diberikan.

2. Reliability, atau kehandalan yaitu kemampuan dalam memberikan pelayanan sesuai yang dijanjikan secara akurat dan terpercaya.

3. Responsiveness, atau tanggapan yaitu suatu kemauan untuk membantu dan memberikan pelayanan yang cepat dan tepat kepada masyarakat dengan menyampaikan informasi yang jelas.

4. Assurance, atau jaminan dan kepastian yaitu pengetahuan, kesopansantunan, dan kemampuan para pegawai untuk menumbuhkan rasa percaya terhadap 
pelanggan.Terdiri dari beberapa komponen di antaranya adalah komunikasi, kredibilitas, keamanan, kompetensi dan sopan santun.

5. Empathy, yaitu memberikan perhatian yang tulus dan bersifat individual atau pribadi yang diberikan kepada pelanggan dengan berupaya memahami keinginan pelanggan.

\section{Pemerintah Kecamatan}

Sarundajang (2000:180), mengemukakan Kecamatan adalah suatu wilayah yang ditempati sejumlah penduduk yang mempunyai organisasi pemerintahan langsung dibawah kabupaten atau kota yang tidak bekerja menyelenggarakan pemerintahan sendiri.

Berdasarkan Undang-Undang Nomor 32 Tahun 2004 pasal 126 ayat 2 bahwa "Kecamatan sebagaimana dimaksud pada ayat 1 dipimpin oleh Camat yang dalam pelaksanaan tugasnya memperoleh pelimpahan sebagian wewenang Bupati untuk menagani sebagian urusan otonomi daerah". Pemerintah daerah melalui Camat berwenang dalam meningkatkan kinerja pada lingkungan pegawai negeri di tingkat kecamatan serta melaporkan hasil pembinaan tersebut kepada bupati.

Kecamatan merupakan perangkat daerah sebagai pelaksana teknis kewilayahan yang memepunyai wilayah kerja tertentu dan dipimpin oleh seorang camat berkedudukan dibawah dan bertanggung jawab kepada Bupati melalui Sekretaris Daerah. Pemerintah Kecamatan menjadi ujung tombak pelayanan umum di daerah. Terdapat cukup banyak jenis pelayanan yang dibutuhkan masyarakat dan harus diurus di tingkat Kecamatan, seperti urusan e-KTP, Akta Kelahiran, juga pengurusan berbagai perijinan. Selain melayani berbagai urusan pelayanan administratif kependudukan, pemerintah kecematan juga mengembangkan tugas melaksanakan pelayanan dasar sektoral, mulai dari urusan ketertiban dan keamanan, pendidikan, kesehatan, pengentasankemiskinan,pemberdayaan masyarakat, dan upaya- upaya konkrit mensejahterakan masyarakat.

\section{Efektivitas Pelayanan Pembuatan e-KTP}

Efektivitas Pelayanan Publik merupakan pengukuran dalam tercapainya sasaran dan tujuan yang telah ditetapkan sebelumnya. Menurut Sondang P (1997:151), menyatakan bahwa efektivitas pelayanan publik berarti penyelesaian pekerjaan tepat pada waktu yang telah ditentukan, artinya pelaksanaan suatu tugas dinilai baik atau tidak sangat bergantung pada penyelesaian tugas tersebut dengan waktu yang telah ditetapkan.

Efektivitas kinerja suatu organisasi sangat bergantung pada efektivitas kerja dari orang-orang yang bekerja didalamnya. Sangat sulit mengukur efektivitas kerja karena penilaiannya sangat subjektif dan bergantung pada masing-masing orang yang menerima pelayanan tersebut. Oleh karena itu dibutuhkan pelayanan yang prima dari aparatur agar tercapai pelayanan yang memuaskan bagi masyarakat.

Menurut Inu Kencana (2009:116-117), Pelayanan terdiri dari tiga unsur pokok, yaitu sebagai berikut :

1. Biayanya relatif harus lebih rendah 
2. Waktu untuk mengerjakan relatif cepat

3. Mutu yang diberikan relatif lebih bagus

e-KTP (Elektronik Kartu Tanda Penduduk) adalah identitas resmi seseorang penduduk di Indonesia yang diperoleh setelah yang bersangkutan berusia 17 tahun (keatas). E-KTP berlaku selama 5 tahun, dan bagi penduduk yang berusia 60 tahun keatas berlaku seumur hidup. E-KTP berisi informasi mengenai sang pemilik kartu.

Adapun syarat dan prosedur dalam pengurusan e-KTP pada Kantor Kecamatan Baamang adalah sebagai berikut:

a. Syarat

1. Berusi 17 tahun;

2. Menunjukkan surat pengantar dari kepala desa/kelurahan;

3. Mengisi formulir F1.01 (bagi penduduk yang belum pernah mengisi/belum ada data di sistem informasi administrasi kependudukan) ditanda tangani oleh kepala desa/kelurahan;

4. Fotocopy Kartu Keluarga.

b. Prosedur

1. Pemohon datang ketempat pelayanan membawa surat panggilan;

2. Pemohon menunggu pemanggilan nomor antrian;

3. Pemohon menuju loket yang telah ditentukan;

4. Petugas melakukan verifikasi data penduduk dengan basis data;

5. Petugas mengambil foto pemohon secara langsung;

6. Pemohon membubuhkan tanda tangan pada alat perekam tanda tangan;

7. Selanjutnya dilakukan perekaman sidik jari dan pemindaian retina mata;

8. Petugas membubuhkan tanda tangan dan setempel pada surat panggilan yang sekaligus sebagai bukti bahwa penduduk telak melakukan perekaman foto, tanda tangan dan sidik jari;

9. Pemohon dipersilahkan pulang untuk menunggu hasil proses percetakan 2 minggu setelah pembuatan.

10. Masa berlaku e-KTP adalah seumur hidup dan pembuatan e-KTP tidak dikenakan biaya.

\section{Faktor-faktor yang mempengaruhi Pelayanan Pembuatan e-KTP}

Adapun faktor yang mempengaruhi efektivitas pelayanan pembuatan e-KTP yaitu :

i. Kemampuan pegawai

Yakni potensi seseorang dalam melaksanakan tugasnya untuk mencapai tujuan organisasi secara optimal dengan sumber daya yang ada. Aparatur pegawai merupakan alat untuk menggerakkan segala kegiatan organisasi khususnya pegawai pelaksana kegiatan pelayanan.

Kemampuan pegawai itupun dapat dilihat dari :

a. Tingkat Pendidikan 
Dari tingkat pendidikan yang pernah diikuti oleh seorang pegawai akan menentukan kemampuan pegawai itu sendiri, dan dengan pengetahuan yang dimiliki maka pengetahuan tersebut sangat menentukan dan mempengaruhi hidupnya. Pendidikan tersebut juga dipergunakan untuk mempersiapkan pegawai untuk memikul tanggung jawab yang berbeda, lebih rendeh atau lebih tinggi dalam suatu organisasi. Dengan demikian maka pegawai akan mengemban tugas dengan penuh tanggung jawab sehingga prestasi kerjanya juga semakin baik.

b. Pengalaman kerja

Pengalaman ini didapat dari masa kerja yang ditempuh pegawai, dengan semakin banyaknya waktu yang dihabiskan untuk bekerja maka pengalaman ataupun kemahiran dan keterampilan dalam bidang tugas yang dilaksanakannya akan semakin baik. Dari pengalaman yang didapat diharapkan kemampuan aparatur dalam melaksanakan tugasnya dapat terlaksana sesuai tujuan yang diharapkan.

\section{c. Pembinaan pegawai}

Pembinaan yang rutin dan teratur sebagai upaya mendayagunakan terhadap peranan dan fungsi aparatur agar mampu melaksanakan tugasnya sesuai dengan wewenang dan tanggung jawab yang diberikan kepadanya. Dengan demikian pembinaan tersebut akan dapat mendorong dan mengembangkan kemampuan seseorang kearah yang lebih baik. Pembinaan juga dilakukan sebagai bentuk pengembangan kemampuan pegawai melalui pendidikan dan sesuai dengan bidang tugas masing-masing. Dalam hal ini pembinaan dilakukan untuk meningkatkan kemampuan aparatur dalam hubungannya dengan peningkatan sistem pelayanan yang dilakukan oleh pemerintah aparatur Kecamatan Baamang.

ii. Fasilitas kerja

Fasilitas kerja merupakan sarana dan prasarana yang mendukung dalam kelancaran pelaksanaan tugas-tugas yang harus diselesaikan, khususnya dalam mewujudkan peningkatan pelayanan kepada masyarakat pada kantor Kecamatan Baamang Kabupaten Kotawaringin Timur (Frendy 2005:22).

\section{METODE PENELITIAN}

Lokasi penelitian ini adalah Kantor Kecamatan Baamang Kabupaten Kotawaringin Timur. Jenis penelitian yang digunakan dalam penelitian ini adalah penelitian kualitatif yakni metode penelitian yang berlandaskan pada filsafat postpositivisme, digunakan untuk meneliti pada kondisi objek yang alamiah, (sebagai lawannya adalah eksperimen) dimana peneliti adalah sebagai instrumen kunci, pengambilan sumber data dilakukan secara purposive dan snowball, teknik pengumpulan data dengan triangulasi (gabungan), analisis data bersifat induktif/kualitatif, dan hasil penelitian kualitatif lebih menekankan makna dari pada generalisasi (Sugiyono 2008:15). Teknik pengumpulan data menggunkan observasi, wawancara dan dokumentasi. Analisis data menggunakan metode triangulasi yakni reduksi data, penyajian data dan penarikan kesimpulan. 


\section{HASIL PENELITIAN DAN PEMBAHASAN}

\section{Kesesuaian Cara Kerja Pegawai Dengan Sistem dan Prosedur Kerja Pegawai Pada Kantor Kecamatan Baamang}

Pemerintah Kecamatan Baamang, khususnya dalam bidang pembuatan e-KTP banyak membuat kebijakan, strategi, dan program dalam membangun kepercayaan masyarakat terhadap pelayanan publik agar terwujud pelayanan yang efektif dan berkualitas yang sesuai dengan sistem dan prosedur kerja yang ada. Berdasarkan hasil analisis yang diperoleh penulis bahwa pegawai pada Kantor Kecamatan Baamang sudah bekerja dengan sistem dan prosedur yang ada serta transparan dan akuntabel dalam memberikan informasi terutama dalam hal pelayanan pembuatan e-KTP sehingga memudahkan masyarakat yang datang untuk memerlukan jasa pelayanan. Akan tetapi disisi lain, pelayanan belum dapat dikatakan baik karena faktor pegawai masih ada yang terlambat untuk datang ke kantor sehingga hal ini dapat berpengaruh pada kinerja pelayanan yang mereka berikan kepada masyarakat.

Berdasarkan dari hasil analisis dapat disimpulkan bahwa kinerja pegawai pada Kantor Kecamatan Baamang sesuai berdasarkan teori menurut Moenir (2000:123-124) dan teori Osbone (1998:31) bahwa suatu pelayanan akan terlaksana dengan baik dan memuaskan apabila didukung oleh faktor diantaranya adalah adanya aturan yang memadai, pelayanan yang sama bagi semua, pelayanan yang berhubungan dengan kebutuhan serta kesadaran para pejabat pemimpin dan pelaksana.

\section{Pegawai Menguasai Dan Memahami Hal-Hal Teknis Pekerjaan Pada Kantor Kecamatan Baamang}

Dalam memberikan pelayanan yang baik dan efektif kepada masyarakat, aparatu pemerintah dituntut dapat memahami dan menguasai hal-hal teknis dalam pekerjaannya, agar mampu meminimalisir resiko dari dampak kesalahan yang akan mungkin terjadi dalam pelayanan yang diberikan kepada masyarakat agar pelayanan dapat berjalan sesuai dengan baik dan lancar. Upaya menciptakan kinerja pegawai dalam melaksanakan tugasnya agar tidak tumpang tindih, maka perlu dibuat uraian hal teknis pekerjaan yang jelas. Hal tersebut dilakukan agar pelayanan yang ada dapat terlaksana dengan baik. Pentingnya pegawai mampu menguasai dan memahami hal teknis pekerjaannya agar pelayanan yang mereka lalukan dapat tepat sasaran sehingga menghasilkan rincian tugas yang baik dan benar, karena pemberian pelayanan yang memuaskan merupakan tujuan yang diinginkan oleh masyarakat.

Berdasarkan dari hasil analisis dapat disimpulkan bahwa kinerja pegawai pada Kantor Kecamatan Baamang sesuai berdasarkan teori Parasuraman dalam Lupiyoadi (2001) bahwa dalam hal pelayanan, pegawai harus mampu memberikan pelayanan sesuai yang dijanjikan secara akurat dan terpercaya, serta pelayanan yang diberika tersebut harus tulus dan bersifat individual atau pribadi yang diberikan kepada pelanggan dengan berupaya memahami keinginan pelanggan. 


\section{Adanya Lokasi Tempat Pelayanan Pada Kantor Kecamatan Baamang}

Lokasi tempat pelayanan juga sangat berpengaruh, karena hal tersebut menyangkut lokasi yang nyaman dan mudah dijangkau oleh setiap masyarakat setempat sehingga memudahkan masyarakat menjangkau lokasi untuk mendapatkan pelayanan mengenai kepentingan mereka.

Berkaitan dengan hal tersebut, dari hasil analisis dapat disimpulkan bahwa kinerja pegawai pada Kantor Kecamatan Baamang sesuai berdasarkan teori menurut Parasuraman dalam Lupiyoadi (2001) bahwa pelayanan yang ada akan semakin baik jika dipengaruhi juga oleh penampilan dan sarana serta prasarana fisik dan keadaan lingkungan sekitarnya.

\section{Kejelasan Informasi Dan Prosedur Pembuatan E-KTP pada Kantor Kecamatan Baamang}

Informasi merupakan kebutuhan pokok setiap orang bagi pengembangan pribadi dan lingkungan dan merupakan salah satu ciri penting negara demokratis yang menjunjung tinggi kedaulatan rakyat untuk mewujudkan penyelenggaraan negara yang baik. Keterbukaan informasi publik merupakan sarana dalam mengoptimalkan pengawasan publik terhadap penyelenggaraan negara dan Badan Publik lainnya dan segala sesuatu yang berakibat pada kepentingan publik sebagaimana yang diamanatkan dalam Undang-Undang Nomor 14 Tahun 2008.

Dalam prosedur pelayanan, proses yang dilakukan sejalan dengan tujuan yang ingin dicapai, karena prosedur pelayanan yang sesuai dapat meningkatkan kinerja pelayanan itu sendiri. Prosedur pelayanan menyangkut saat masyarakat datang dan menghubingi petugas (loket) untuk menyampaikan kebutuhan dan menyerahkan persyaratan yang dibutuhkan, sampai mereka mendapatkan pelayanan yang mereka butuhkan melalui prosedur yang baik, tidak berbelit-belit, dan mudah diikuti.

Berdasarkan dari hasil analisis dapat disimpulkan bahwa kinerja pegawai pada Kantor Kecamatan Baamang sesuai berdasarkan teori menurut Parasuraman dalam Lupiyoadi (2001) dan menurut Sinambela (2006:6) bahwa harus ada kemauan untuk membantu dan memberikan pelayanan kepada masyarakat dengan menyampaikan informasi yang jelas, kesopansantunan dari para pegawai untuk menumbuhkan rasa percaya terhadap pelanggan, serta pelayanan yang bersifat terbuka, mudah dan dapat diakses oleh semua pihak yang membutuhkan dan disediakan secara memadai dan mudah dimengerti oleh kalangan masyarakat.

Dalam prosedur pelayanan, proses yang dilakukan sejalan dengan tujuan yang ingin dicapai, karena prosedur pelayanan yang sesuai dapat meningkatkan kinerja pelayanan itu sendiri. Prosedur pelayanan menyangkut saat masyarakat datang dan menghubingi petugas (loket) untuk menyampaikan kebutuhan dan menyerahkan persyaratan yang dibutuhkan, sampai mereka mendapatkan pelayanan yang mereka butuhkan melalui prosedur yang baik, tidak berbelit-belit, dan mudah diikuti. 


\section{Ketepatan Waktu dan Biaya Pelayanan Pembuatan E-KTP Pada Kantor Kecamatan Baamang}

Ketepatan waktu dan biaya pelayanan merupakan priorotas utama dalam hal pelayanan, karena jika pekerjaan dapat terselesaikan dengan tepat waktu dan biaya yang terjangkau maka kualitas pelayanan tersebut sudah semakin baik. Tetapi terkadang penggunaan tepat waktu untuk masing-masing orang berbeda-beda sesuai dengan tingkat kepentingan pelayanan yang mereka berikan serta pemahaman mereka.

Disini pegawai harus menekankan prinsip keterbukaan. Prinsip keterbukaan mengandung arti bahwa prosedur / tata cara, persyaratan, satuan kerja / pejabat penanggung jawab pemberi pelayanan, waktu penyelesaian, rincian biaya / tarif serta hal-hal lain yang berkaitan dengan proses pelayanan wajib diinformasikan secara terbuka agar mudah diketahui dan dipahami oleh masyarakat, baik diminta maupun tidak diminta. Prinsip keterbukaan pelayanan memberikan petunjuk untuk menginformasikan secara terbuka segala sesuatu yang berkaitan dengan pelaksanaan pemberian pelayanan kepada masyarakat.

Berkaitan dengan hal tersebut, dari hasil analisis dapat disimpulkan bahwa kinerja pegawai pada Kantor Kecamatan Baamang sesuai berdasarkan teori menurut Sinambela (2006), Sondang P (1997), dan Inu Kencana (2009), yakni pelayanan yang ada harus bersifat terbuka, mudah dan dapat diakses serta mudah dimengerti oleh masyarakat, penyelesaian pekerjaan yang tepat pada waktu yang telah ditentukan, biaya relatif harus lebih rendah serta mutu yang diberikan relatif lebih bagus.

\section{Kemampuan Pegawai}

Pelayanan pembuatan e-KTP pada Kantor Kecamatan Baamang haruslah berkualitas, serta para pegawainya pun harus benar-benar memiliki kemampuan yang tinggi dalam hal pelayanan. Dengan begitu masyarakat dapat mendapatkan kepuasan pelayanan yang diharapkan. Para aparatur harus tau apa yang menjadi kebutuhan masyarakat dan harus dapat melakukan pelayanan dengan standar pelayanan yang berkualitas.

Kemampuan merupakan suatu unsur dalam kematangan aparatur, berkaitan dengan pengetahuan atau keterampilan yang diperoleh dari pendidikan, latihan dan suatu pengalaman. Seorang penyedia layanan akan bisa menjalankan tugasnya dengan baik apabila pegawai tersebut mempunyai kelebihan atau kemampuan baik itu fisik maupun mental, kemampuan berfikir, kemampuan menerapkan keahlian / ketrampilan yang dimiliki, sehingga dengan potensi-potensi tersebut mereka akan mudah untuk melakukan kegiatan dalam mencapai tujuan yang telah ditetapkan.

a. Tingkat Pendidikan Pegawai

Prestasi akademis yang dimiliki pegawai selama mengikuti pendidikan sebelumnya harus dipertimbangkan, khususnya dalam penempatan pegawai tersebut untuk menyelesaikan tugas pekerjaannya, serta mengemban wewenang dan tanggung jawab. Prestasi akademis yang perlu dipertimbangkan tidak terbatas pada jenjang terakhir pendidikan tetapi termasuk jenjang pendidikan yang pernah dialaminya. Pegawai yang memiliki prestasi akademis tinggi harus ditempatkan pada tugas dan 
pekerjaan yang sesuai dengan kemampuannya, sebaliknya pegawai yang memiliki latar belakang akademis rata-rata atau dibawah standar harus ditempatkan pada tugas dan pekerjaan ringan dengan beban wewenang dan tanggung jawab yang relatif rendah.

Berkaitan dengan hal tersebut, dari hasil analisis dapat disimpulkan bahwa kinerja pegawai pada Kantor Kecamatan Baamang sesuai berdasarkan teori menurut Kaho (2002) bahwa pendidikan memberikan kemampuan dan keterampilan kepada manusia untuk merumuskan pikiran, pendapat yang hendak disampaikan kepada orang lain secara logis dan sistematis sehingga mudah dimengerti; pengetahuan yang luas dan mendalam tentang bidang yang dipilh atau dipelajari seseorang; serta melatih manusia untuk berpikir secara rasional dan menggunakan kecerdasan kearah yang tepat.

b. Pengalaman Kerja Pegawai

Pengalaman bekerja banyak memberikan keahlian dan keterampilan kerja. Pengalaman bekerja yang dimiliki seseorang kadang-kadang lebih dihargai daripada tingkat pendidikan yang menjulang tinggi. Pegawai yang berpengalaman dapat langsung menyelesaikan tugas dan pekerjaanya. Pegawai hanya memerlukan pelatihan dan petunjuk yang relatif singkat. Sebaliknya pegawai yang hanya mengandalkan latar belakang pendidikan dan gelar yang disandangnya, belum tentu mampu mengerjakan tugas dan pekerjaan yang diberikan kepadanya dengan cepat.

Berkaitan dengan hal tersebut, dari hasil analisis dapat disimpulkan bahwa kinerja pegawai pada Kantor Kecamatan Baamang sesuai berdasarkan teori menurut Parasuraman dalam Lupiyoadi (2001) bahwa pengalam kerja seseorang sangat berpengaruh pada pengetahuan, kesopansantunan, dan kemampuan para pegawai untuk menumbuhkan rasa percaya terhadap pelanggan.

\section{c. Pembinaan Pegawai}

Pembinaan pegawai dilakukan sebagai bentuk pengembangan kemampuan pegawai sesuai tugas dan bidangnya masing-masing. Pembinaan pembinaan tersebut bisa melalui diklat-diklat menanmbah pengetahuan, keterampilan dan mengubah sikap agar semakin baik potensi yang dimiliki seorang pegawai sehigga semakin berdaya guna untuk mencapai tujuan organisasi.

Berkaitan dengan hal tersebut, dari hasil analisis dapat disimpulkan bahwa kinerja pegawai pada Kantor Kecamatan Baamang sesuai berdasarkan teori menurut Usmara (2002) bahwa pembinaan karier bertujuan untuk pengembangan dan peningkatan kinerja melalui tugas khusus, serta pengembangan untuk membawa pegawai lebih bertanggung jawab lagi terhadap wewenangnya.

\section{Fasilitas Kerja}

Fasilitas kerja adalah sarana pendukung dalam aktivitas organisai berbentuk fisik, dan digunakan dalam kegiatan normal perusahaan, memiliki jangka waktu kegunaan yang relatif permanen dan memberikan manfaat untuk masa yang akan dating. Fasilitas kerja sangatlah penting bagi organisasi, karena dapat menunjang kinerja pegawai, seperti dalam penyelesaian pekerjaan. Kinerja juga merupakan salah satu sarana pendukung untuk menciptakan motivasi kerja terhadap kinerja pegawai. 
Dari hasil analisis peneliti, bahwa sarana dan prasarana yang ada pada kantor Kecamatan Baamang belum memadai dan menunjang para pegawai dalam melaksanakan tugasnya dalam hal alat pendukung pembuatan e-KTP namun disisi lain jika dilihat dari sarana dan prasarana keadaan fisiknya sudah memadai. Dengan sarana dan prasarana yang baik, maka akan dapat tercipta kualitas pelayanan yang baik pula kepada masyarakat.

\section{KESIMPULAN DAN SARAN}

Efektivitas pelayanan pemerintah yakni penyelesaian pekerjaan yang tepat waktu dengan biaya yang relatif rendah untuk mencapai tujuan yang diinginkan dengan memanfaatkan sumber daya yang ada. Efektif atau tidaknya pemerintah dalam hal memberikan pelayanan kepada masyarakat dapat diukur dari tingkat kepuasan masyarakat terhadap pelayanan yang diberikan dan yang mereka terima. Dalam mencapai efektivitas pelayanan yang baik maka diperlukan dukungan serta kerjasama yang baik antar pegawai, untuk itu diperlukan juga strategi yang baik dan siap agar dapat meningkatkan efektivitas pelayanan pemerintah yang semakin memuaskan masyarakat.

Berdasarkan hal tersebut diatas, di satu sisi dapat dianalisis bahwa Pelayanan Pembuatan e-KTP pada Kantor Kecamatan Baamang sudah berjalan baik seperti yang terlihat dari pegawai yang ada sudah menguasai teknis pekerjaannya, memberikan informasi dengan akuntabel dan transpran serta pegawai memiliki kemampuan yang handal baik dalam hal pendidikan, pengalaman maupun pembinaan kerja yang baik. Tetapi disisi lain belum sesuai dengan tujuan karena kurangnya fasilitas alat perekaman data e-KTP yang serta kurang disiplinnya pegawai.

Oleh karena hal tersebut, maka kesimpulan penulis bahwa pelayanan pembuatan e-KTP PADA Kantor Kecamatan Baamang belum efektif sesuai tujuan yang diinginkan. Hal tersebut sangat mempengaruhi kepuasan masyarakat yang menerima pelayanan maupun kualitas pelayanan yang diberikan oleh aparatur.

1. Saran

- Hendaknya pemerintah lebih bisa memperhatikan keperluan masyarakat akan penggunaan E-KTP, karena dengan terbatasnya alat yang dimiliki maka semakin lama juga waktu pemprosesan E-KTP tersebut sehingga membuat masyarakat semakin enggan membuat E-KTP yang semestinya wajib dimiliki oleh masyarakat.

- Disarankan kepada aparatur pemerintah Kecamatan Baamang baik camat, sekertaris camat, sub bagian pelayanan umum dan seksi pemerintahan serta para pegawai yang bekerja dalam menjalangkan tugas dan perannya sebagai pelayan publik untuk dapat bekerja secara lebih baik lagi, disiplin, dan profesionalisme dalam memberikan pelayanan kepada masarakat serta mengunakan pendekatan yang sesuai dengan situasi dan kondisi masarakat agar pelayanan publik di wilayah Kecamatan Baamang khususnya mengenai efektivitas pelayanan E-KTP bisa berjalan dengan baik. 
- Hendaknya juga masyarakat memiliki kesadaran yang tinggi untuk berpartisipasi membantu pemerintah Kecamatan dalam penyelengaraan pelayanan publik khususnya pelayanan E-KTP. Karena tanpa dukungan serta partisipasi masarakat pelayanan publik tidak bisa berjalan dengan baik.

\section{DAFTAR PUSTAKA}

Astuti. 2004. Kinerja Pemerintah: Good Government. Jakarta: Rieneka Cipta.

Black J and Dean J. 2011. Metode dan Masalah Penelitian Sosial. Bandung: Refika Aditama.

Chairuman. 2002. Kinerja Birokrasi Pemerintah.Jakarta: PT.Bumi Aksara.

Fanar, Agus. 2009. Standar Pelayanan Publik Pemda. Bantul: Kreasi Wacana.

Handoko. 1997. Pelayanan Publik. Bandung: Alfabeta.

Kaho. 2002. Manajemen Pelayanan Publik. Bandung: Alfabeta.

Kencana, Inu. 2009. Sistem Administrasi Negara Republik Indonesia. Jakarta: PT.Bumi Aksara.

Kencana, Inu. 2011. Manajemen Pemerintah. Bandung: PRC

Keputusan Menpan No.63/Kep./M.PAN/7/2003, tentang Pedoman Umum Penyelenggaraan Layanan Publik.

Lupiyoadi .2011. Pelayanan Publik. Bandung: Alfabeta.

Margono, S. 2007 .Metodologi Penelitian Pendidikan.Jakarta:Rineka Cipta.

Monir. 2003. Teori dan Konsep Administrasi Publik.Bandung: Alfabeta.

Mulyana, Deddy. 2010. Metodologi Penelitian Kualitatif. Bandung. PT Remaja: Rosdakarya

Osbone. 1988. Pelayanan Publik.Jakatra: Rieneka Cipta.

Pasolong, Harbani. 2011.Teori ADMINISTRASI PUBLIK. Bandung: Alfabeta.

Sarundajang. 2000. Kinerja Pemerintah Daerah.Bandung: PRC.

Silalahi, Ulber. 2012. Metode Penelitian Sosial.Bandung: PT Refika Aditama.

Sinambela, Lijan. 2011. Reformasi Pelayanan Publik.Jakarta: PT.Bumi Aksara.

Sondang. 1997. Pelayanan Publik. Bandung: PRC.

Steers, Richard. 1980. Administrasi Publik.Bandung: Alfabeta.

Steers, Richard.1990. Pelayanan Organisasi Publik. Bandung: Alfabeta.

Steers, Richard. 2011. Ragam Jurnal Pengembangan Humaniora vol.11 No. 1. Bandung: Alfabeta. 
Sugiyono. 2013. Metode Penelitian Kuantitatif Kualitatif dan R\&D. Bandung: Alfabeta.

Undang- Undang Nomor 23 tahun 2006

Undang-Undang Nomor 14 Tahun 2008.

Undang-Undang Pelayanan Publik No. 25 tahun 2009.

Usmara, Usi. 2002. Kinerja: Pelayanan Publik.Jakarta:Rieneka Cipta.

Zuliyanti. 1986. Kamus Umum Bahasa Indonesia.

Zuliyanti. 1989. Ensiklopedi Administrasi.

Zuliyanti. 2005. Konsep Pelayanan Publik.Jakarta:Rieneka Cipta. 